\title{
PROBLEMS OF MEDICAL REHABILITATION IN PATIENTS AFTER A TRANSIENT ISCHEMIC ATTACK
}

\author{
Kostenko EV $\bowtie$, Eneeva MA, Kravchenko VG
}

Moscow Centre for Research and Practice in Medical Rehabilitation, Restorative and Sports Medicine, Moscow, Russia

\begin{abstract}
The efficacy of rehabilitation in post-TIA patients still remains a clinical challenge, considering the combined burden of the primary disease and comorbidities. The aim of this study was to provide a rationale for introducing psychological counseling into post-TIA rehabilitation programs after studying the presentations of cognitive and emotional impairments developed after this cerebrovascular event. We analyzed in- and outpatient medical records of 351 participants (the mean age was $58.6 \pm 2.2$ years) who had experienced a TIA. Data was collected from forms $0.25 / y$ and 003/y, medical/social questionnaires and also included MMSE and HADS scores. We found that $\mathrm{Cl}$ and MD ranked second after cardiovascular diseases among the comorbidities in post-TIA patients (186.8 cases per 100 patients). We conclude that rehabilitation of post-TIA patients should involve a multidisciplinary team of experts including a psychotherapist or a clinical psychologist who will provide psychological counselling.
\end{abstract}

Keywords: transient ischemic attack, neuropsychological disorders, cognitive impairment, mood disorders, medical rehabilitation

Author contribution: Kostenko EV — study conception and design, data analysis and interpretation, manuscript revision; Eneeva MA — study design, data analysis and interpretation, manuscript draft; Kravchenko VG — data analysis and interpretation, manuscript draft.

Compliance with ethical standards: the study was approved by the Ethics Committee of Moscow Centre for Research and Practice in Medical Rehabilitation, Restorative and Sports Medicine (Protocol № 7 dated June 21, 2017).

$\triangle$ Correspondence should be addressed: Elena V. Kostenko

Baumanskaya 70, Moscow, 105007; ekostenko58@mail.ru

Received: 24.05.2019 Accepted: 07.06.2019 Published online: 08.06.2019

DOI: $10.24075 /$ brsmu.2019.038

\section{АКТУАЛЬНЫЕ ВОПРОСЫ ОРГАНИЗАЦИИ МЕДИЦИНСКОЙ РЕАБИЛИТАЦИИ ПАЦИЕНТОВ, ПЕРЕНЕСШИХ ТРАНЗИТОРНУЮ ИШЕМИЧЕСКУЮ АТАКУ}

\author{
Е. В. Костенко $₫$, М. А. Энеева, В. Г. Кравченко
}

Московский научно-практический центр медицинской реабилитации, восстановительной и спортивной медицины, Москва, Россия

\begin{abstract}
Повышение эффективности реабилитационных мероприятий у пациентов, перенесших транзиторную ишемическую атаку (ТИА), с учетом особенностей основного и ведущих сопутствующих заболеваний остается актуальной задачей. Целью исследования было на основании изучения особенностей когнитивныхи эмоциональных нарушений обосновать значение психокоррекции в комплексе реабилитационных мероприятий у пациентов, перенесших ТИА. Была изучена и проанализирована заболеваемость у 351 пациента, перенесшего ТИА. Средний возраст обследованных пациентов составил 58,6 + 2,2 года. Для сбора информации проводили выкопировку данных из медицинских карт амбулаторных больных (форма 0,25/у) и медицинских карт стационарных больных (форма 003/y), в том числе данных опроса пациентов по Анкете медико-социальной характеристики пациентов, учитывали также данные шкал MMSE, HADS. Выявлено, что второе место по уровню заболеваемости у пациентов, перенесших ТИА, после заболеваний сердечнососудистой системы занимают психические расстройства, распространенность которых составила 186,8 случая на 100 пациентов. Важное место в программах медико-социальной реабилитации пациентов, перенесших ТИА, должна занимать коррекция психических расстройств с участием психотерапевта, медицинского психолога в составе мультидисциплинарной бригады.
\end{abstract}

Ключевые слова: транзиторная ишемическая атака, нейропсихологические расстройства, когнитивные нарушения, эмоциональные расстройства, медицинская реабилитация

Информация о вкладе авторов: Е. В. Костенко - концепция и дизайн исследования, анализ и интерпретация данных, внесение принципиальных изменений в текст статьи; М. А. Энеева - дизайн исследования, анализ и интерпретация данных, подготовка текста статьи; В. Г. Кравченко - анализ и интерпретация данных, подготовка текста статьи.

Соблюдение этических стандартов: исследование одобрено этическим комитетом Московского научно-практического центра медицинской реабилитации, восстановительной и спортивной медицины (протокол № 7 от 21 июня 2017 г.)

$\bowtie$ Для корреспонденции: Елена Владимировна Костенко

ул. Бауманская, д. 70, г. Москва, 105007; ekostenko58@mail.ru

Статья получена: 24.05.2019 Статья принята к печати: 07.06.2019 Опубликована онлайн: 08.06.2019

DOI: $10.24075 /$ vrgmu.2019.038

A transient ischemic attack (TIA) is a type of an acute cerebrovascular syndrome that is not accompanied by persistent neurological symptoms characteristic of a focal brain injury. Because TIA symptoms rapidly resolve on their own, patients often ignore them as insignificant and do not seek immediate medical help; for the same reason, doctors may not recognize the short-lived symptoms as TIA [1].

TIA can be a harbinger of a much more devastating acute vascular event; therefore, its clinical importance and prognostic value should not be underestimated. Post-TIA patients are at a higher risk of myocardial infarction (MI), stroke or death within 5 years after TIA [1-4]. But apart from being a marker of an upcoming cardio or cerebrovascular episode, TIA is also linked to the development of such nonfatal conditions as cognitive impairment $(\mathrm{Cl})$ and mood disorders by a few Russian and international researchers [5, 6].

Studies of cognitive function in hypertensive post-TIA patients reveal that such patients suffer from $\mathrm{Cl}$; they also demonstrate an association between $\mathrm{Cl}$ and changes to brain morphology induced by elevated blood pressure. Interestingly, $\mathrm{Cl}$ does not have any clinically or functionally significant impact on the patients before TIA occurs [5]. Among post-TIA patients, $\mathrm{Cl}$ is more common in men than women [6]. Research into structural and morphological changes to brain matter in patients with TIA and $\mathrm{Cl}$ has found signs of cerebral atrophy localized to the thalamus, hypothalamus and the dentate gyrus 
[5-7]. The researchers suggest that cognitive and emotional impairments in this cohort are a result of brain matter atrophy.

$\mathrm{Cl}$ is diagnosed in over $40 \%$ of post-TIA patients [4]. Researchers are particularly interested in studying the severity and clinical presentations of cognitive and mood disorders, their prognostic value and effect on a patient's daily life.

Microstructural tissue damage induced by TIA causes cortical and subcortical structures to disconnect. Although motor function is spared, the disconnection promotes development of neuropsychological disorders that have no lesser impact on the patient than post-stroke motor disorders. Exploration of and interaction with the outside world rely on intact cognitive function; in post-TIA patients, its deficit is exacerbated by emotional lability [7].

In order to improve the outcome of rehabilitation programs and to reduce the risk of recurrence in post-TIA patients, the following parameters should be factored into: the patterns of neurological and mental disorders that accompany TIA, possible comorbidities, patients' social and hygienic characteristics. This will help physicians to tailor rehabilitation to the individual patient.

The aim of this study was to provide a rationale for introducing psychological counseling into rehabilitation programs for post-TIA patients after studying the presentations of cognitive and emotional impairments in such patients.

\section{METHODS}

The study of cognitive and emotional impairments in 351 patients was based on the analysis of out- and inpatient medical records (Forms 0.25/y and 003/y) and medical/social questionnaires. For female participants, the mean age was $59.6 \pm 2.3$ years; for male participants, $57.6 \pm 2.2$ years. The mean age of the entire cohort was $58.6 \pm 2.2$ years.

$\mathrm{Cl}$ and its severity were inferred from the patients' medical records that included Mini Mental State Examination (MMSE) scores [8]. The severity of mood disorders was evaluated based on the Hospital Anxiety and Depression scale (HADS) [9], which is used in the setting of a GP practice.

Of all female patients, $46.7 \%$ were retired but working. Most patients had a college $(47.0 \% ; n=165)$ or university $(35.3 \%$; $n=124)$ degree. The majority of the patients were not satisfied with their current job $(62.1 \% ; n=218)$. One in 5 patients was either widowed or unmarried (19.9\%; $n=70)$; this subgroup was dominated by women. We discovered that $79.7 \%$ $(n=280)$ of the patients lived with their families; $5.6 \%(n=20)$ had relatives but lived separately; $14.7 \%(n=51)$ did not have a family. Permanent disabilities were observed in 73 patients (20.8\%); of them 58 (79.4\%) had a 3rd degree disability, and only 15 (20.6\%) had a 2nd degree disability.

Information selected from the medical records was entered into special case sheets and processed in Excel (Microsoft;
USA) and Statistica 8.0 (StatSoft Inc; USA). The results were presented as the mean + the mean error $(\mathrm{M} \pm \mathrm{m})$ and the median (Me) for normally distributed variables (the Kolmogorov-Smirnov test). Qualitative characteristics were presented as absolute and relative frequencies (\%). The significance of differences was assessed using Student's $t$-test and the nonparametric $\chi 2$-test. Spearman's rank correlation coefficient was used to measure a correlation between two variables. Differences were considered significant at $p<0.05$.

\section{RESULTS}

Detected comorbidities were categorized according to the International Statistical Classification of Diseases and Related Health Problems (ICD-10). In terms of prevalence, circulatory system diseases ranked first (32.6\%), mental disorders ranked second (31.5\%) and endocrine disorders ranked third (15.5\%). These 3 groups amounted to $79.6 \%$ of all pathologies detected in our post-TIA patients. Table 1 summarizes distribution of various circulatory system diseases among the study participants.

We have found that 312 (89\%) patients suffered from comorbid conditions of the circulatory system varying in their severity. Two or more comorbid circulatory system diseases were observed in 130 (37.0\%) post-TIA patients.

In terms of prevalence, mental disorders ranked second after circulatory system diseases in post-TIA patients (186.8 cases per 100 patients; Table 2).

Fig. 1 shows how mental disorders were distributed in the studied cohort of patients.

Organic anxiety disorder was diagnosed in $72.9 \%$ of 351 patients. $\mathrm{Cl}$ occurred in $31.1 \%$ of the patients and was represented by moderate $\mathrm{Cl}(19.9 \%)$, mild dementia $(7.7 \%)$, and moderate dementia (3.4\%). Depression was observed in $17.7 \%$ of the participants; of them $12.5 \%$ had subclinical depression, $3.4 \%$ had a mild depressive episode, and $1.7 \%$ suffered from moderate depression.

About 1 in every 2 patients (45.7\%) was afflicted with a combination of $\mathrm{Cl}$ and depression or cooccurring depression and anxiety. $\mathrm{Cl}$ was most common in patients aged over 60 years, with no significant differences in prevalence between males and females. Mood disorders were more frequent in women aged 50-59, whereas depression was more common in men over 70.

Mood disorders were characterized by low mood, sadness, tension, worrying thoughts, and anxiety. The following symptoms were noticed in the majority of patients: low intellectual productivity, lack of goals, decreased motivation to come back to work and resume social contacts, difficulty concentrating, inertia, and reluctance to take part in rehabilitation programs.

The analysis revealed a strong positive correlation between $\mathrm{Cl}$ and recurrence of an acute cerebrovascular event (TIA,

Table 1. The frequency of circulatory system diseases diagnosed in post-TIA patients

\begin{tabular}{|l|c|c|}
\hline \multicolumn{1}{|c|}{ Condition } & \multicolumn{2}{c|}{ Number of cases } \\
\cline { 2 - 3 } & Abs. & $\%$ \\
\hline Cerebrovascular diseases & 312 & 89.0 \\
\hline Hypertensive heart disease & 241 & 68.7 \\
\hline Atherosclerosis & 185 & 73.7 \\
\hline Ischemic heart disease & 141 & 56.2 \\
\hline Atherosclerotic heart disease & 82 & 58.2 \\
\hline Old myocardial infarction & 37 & 26.2 \\
\hline Other forms of chronic ischaemic heart disease & 22 & 15.6 \\
\hline Occlusion and stenosis of cerebral arteries, not resulting in cerebral infarction & 20 & 14.2 \\
\hline
\end{tabular}


ischemic or hemorrhagic stroke) $(r=0.724 ; p<0.05)$, as well as between depression and recurrence of an acute cerebrovascular event (TIA, ischemic or hemorrhagic stroke) $(r=0.736 ; p<0.05)$.

Neuropsychological disorders and cardiovascular conditions cooccurred in 213 (60.7\%) patients. Hypertension was observed in 161 (75.6\%) patients (Tables 3-5). A direct, strong and reliable correlation was established between the severity of $\mathrm{Cl}$ and hypertension $(r=0.95 ; p<0.05)$, as well as between the severity of mood disorders and hypertension $(r=0.95 ; p<0.05)$.

Neuropsychological disorders cooccurred with coronary artery disease (CAD) in 101 (47.4\%) patients; Ml was observed in 21 cases (20.8\% patients with CAD; Table 6). We analyzed a correlation between cognitive/mood disorders and CAD in the presence or absence of $\mathrm{Ml}$. The analysis revealed a strong positive correlation between the presence of $\mathrm{CAD}$ and $\mathrm{Cl}$ $(r=0.87 ; p<0.05)$; in the patients with $\mathrm{Ml}$, the correlation was similar $(r=0.97 ; p<0.05)$. The analysis also yielded a positive and reliable correlation between $\mathrm{CAD}$ and $\mathrm{MD}(r=0.93$; $p<0.05)$. The correlation between depression and CAD with $\mathrm{Ml}$ was stronger than between depression and CAD without MI.

\section{DISCUSSION}

A few authors report the presence of vascular $\mathrm{Cl}$ varying in severity in $70-80 \%$ of patients with acute and chronic cerebrovascular conditions $[10,11]$. Minor strokes are often the cause of $\mathrm{Cl}$; therefore, every patient who has experienced a TIA or a stroke should have their cognitive function evaluated [12]. Neuropsychological disorders that often have subclinical manifestations can cause emotional distress, behavioral or adjustment disorders in patients with cerebrovascular conditions [12]. Cl signals the unfavorable course of a primary cerebrovascular disorder and is an indicator of low cerebral reserve, which increases the risk of a recurrent vascular event in patients with $\mathrm{Cl}[11]$.

The data on $\mathrm{Cl}$ and $\mathrm{MD}$ presented in both Russian and international literature covers mainly post-stroke patients; that said, the studied cohorts might have also included patients with TIA. So far, there have been no large-scale studies of neuropsychological conditions in post-TIA patients. The data described in the literature was collected from small cohorts of patients (less than 100) $[13,14]$.

In post-TIA patients, MD can affect the course of the illness, trigger another stroke or impede rehabilitation [15]. In the cited work, emotional disturbances were assessed using the HADS scale. It was hypothesized that the central focus of post-TIA rehabilitation should be on psychological counseling. Some authors believe that post-TIA patients develop anxiety and depression due to vascular damage and a profound psychological response to the event; therefore, a wellstructured multidisciplinary multifactorial program that includes control over vascular risk factors as part of risk mitigation will help to bring down HADS scores and reduce the prevalence of depression a year after the vascular event [16]. Another

Table 2. Prevalence of mental disorders in post-TIA patients

\begin{tabular}{|l|c|c|}
\hline \multicolumn{1}{|c|}{ Condition } & Abs. & $\%$ \\
\hline Cognitive impairement: & 109 & 31.1 \\
\hline MCD & 70 & 19.9 \\
\hline Mixed cortical and subcortical vascular dementia, mild form & 27 & 7.7 \\
\hline Mixed cortical and subcortical vascular dementia, moderate form & 12 & 3.4 \\
\hline Organic anxiety disorder & 256 & 12.9 \\
\hline Organic mood disorder: & 62 & 17.7 \\
\hline Subclinical depression & 44 & 12.5 \\
\hline Mild depression & 12 & 3.4 \\
\hline Moderate depression & 6 & 1.7 \\
\hline Organic emotionally labile disorder & 58 & 16.5 \\
\hline Total: & 656 & 186.8 \\
\hline
\end{tabular}

Note: MCD — mild cognitive disorder

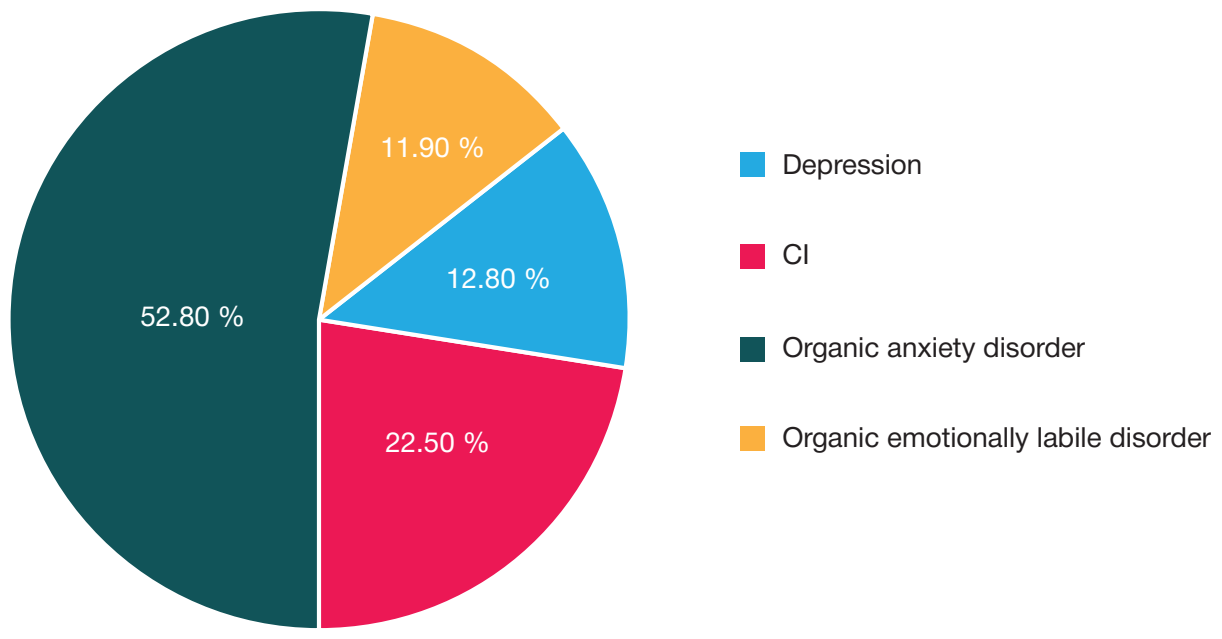

Fig. 1. Distribution of mental disorders in post-TIA patients 
Table 3. Prevalence of neuropsychological (cognitive and mood) disorders in post-TIA patients with hypertensive heart disease

\begin{tabular}{|l|c|c|}
\hline \multicolumn{1}{|c|}{ Cognitive impairment } & Number of cases (abs.) & Number of cases with comorbid hypertensive heart disease \\
\hline MCD & 70 & 58 \\
\hline Mild dementia & 27 & 22 \\
\hline Moderate dementia & 12 & 12 \\
\hline MD: & & \\
\hline Subclinical depression & 44 & 38 \\
\hline Mild depression & 12 & 8 \\
\hline Moderate depression & 6 & 5 \\
\hline
\end{tabular}

Note: $M D$ - mood disorders

Table 4. Severity of hypertensive heart disease in post-TIA patients with $\mathrm{Cl}$

\begin{tabular}{|c|c|c|c|c|c|c|c|}
\hline \multirow{2}{*}{$\mathrm{Cl}_{\mathrm{Cl}}^{\mathrm{HHD}}$} & \multicolumn{2}{|c|}{ Stage 1} & \multicolumn{2}{|c|}{ Stage 2} & \multicolumn{2}{|c|}{ Stage 3} & \multirow{2}{*}{$\begin{array}{l}\text { Total } \\
\text { Abs. }\end{array}$} \\
\hline & Abs. & $\%$ & Abs. & $\%$ & Abs. & $\%$ & \\
\hline MCD & 38 & 54.3 & 12 & 17.1 & 8 & 11.4 & 58 \\
\hline Mild dementia & 5 & 18.5 & 10 & 37 & 7 & 26 & 22 \\
\hline Moderate dementia & 1 & 8.3 & 2 & 16.7 & 9 & 75 & 12 \\
\hline Total: & 44 & & 24 & & 24 & & 92 \\
\hline
\end{tabular}

Table 5. Severity of hypertensive heart disease in post-TIA patients with mood disorders

\begin{tabular}{|c|c|c|c|c|c|c|c|}
\hline \multirow{2}{*}{$\mathrm{Cl}$} & \multicolumn{2}{|c|}{ Stage 1} & \multicolumn{2}{|c|}{ Stage 2} & \multicolumn{2}{|c|}{ Stage 3} & \multirow{2}{*}{$\begin{array}{l}\text { Total } \\
\text { Abs. }\end{array}$} \\
\hline & Abs. & $\%$ & Abs. & $\%$ & Abs. & $\%$ & \\
\hline Subclinical MD & 30 & 68.4 & 5 & 11.4 & 3 & 6.8 & 38 \\
\hline Mild depression & 3 & 25 & 4 & 33.3 & 1 & 8.3 & 8 \\
\hline Moderate depression & 0 & 0 & 1 & 16.7 & 4 & 66.7 & 5 \\
\hline Total: & 33 & & 9 & & 8 & & 51 \\
\hline
\end{tabular}

Table 6. Prevalence of $\mathrm{Cl}, \mathrm{MD}$ and $\mathrm{CAD}$ in post-TIA patients

\begin{tabular}{|c|c|c|c|c|c|}
\hline \multirow{2}{*}{$\begin{array}{l}\text { Cognitive impairment } \\
\text { MCD }\end{array}$} & \multirow{2}{*}{$\begin{array}{c}\begin{array}{c}\text { Number of } \\
\text { cases (abs.) }\end{array} \\
70\end{array}$} & \multicolumn{2}{|c|}{$\begin{array}{l}\text { Number of cases of comorbid } \mathrm{Cl} \text { and CAD } \\
(\text { (abs. / \%) }\end{array}$} & \multicolumn{2}{|c|}{$\begin{array}{l}\text { Number of cases of comorbid } \mathrm{Cl} \text { and CAD with MI } \\
\qquad(\text { abs. / \%) }\end{array}$} \\
\hline & & 18 & 25.7 & 5 & 7.1 \\
\hline Mild dementia & 27 & 8 & 29.6 & 3 & 11.1 \\
\hline Moderate dementia & 12 & 4 & 33.3 & 2 & 16.7 \\
\hline \multicolumn{6}{|l|}{ MD: } \\
\hline Subclinical depression & 44 & 32 & 72.7 & 8 & 18.2 \\
\hline Mild depression & 12 & 6 & 50 & 5 & 41.7 \\
\hline Moderate depression & 6 & 4 & 66.7 & 2 & 33.3 \\
\hline
\end{tabular}

study investigated patients' psychosocial response to TIA. The authors were able to identify 6 major reaction patterns, including worrying thoughts about the future/changes in lifestyle, lack of trust, frustration, anxiety, sense of loss, sadness, confusion. Knowledge of such personal reactions to TIA can help to tailor rehabilitation to the needs of an individual patients and transform their usual coping strategies in order to achieve better rehabilitation outcomes [17].

Some authors indicate that $\mathrm{Cl}$ can occur in patients who have already experienced a TIA or a minor stroke [5, 18, 19]. Within 9 months following TIA, one-third of patients develop $\mathrm{Cl}$ interfering with their lifestyle [20].

To sum up, MD and $\mathrm{Cl}$ in post-TIA patients can be used to tailor rehabilitation programs to the needs of an individual patient.
CONCLUSION

$\mathrm{Cl}$ and $\mathrm{MD}$ rank second after cardiovascular diseases among the comorbidities in post-TIA patients (186.8 cases per 100 patients). Mental disorders cooccur with circulatory system diseases in $60.7 \%$ of post-TIA patients. We have established direct, strong and reliable correlations between the severity of $\mathrm{Cl}$ and the presence of hypertensive heart disease $(r=0.95$; $p<0.05$ ), between the severity of mood disorders and hypertensive heart disease $(r=0.95 ; p<0.05)$ and its stage. A combination of neuropsychological disorders and CAD was observed in 47.4\% of post-TIA patients. Therefore, rehabilitation for such patients should be well-structured, multidisciplinary and account for multiple factors, including possible comorbidities among which neuropsychological disorders play a significant role. 
1. Uchijam Sh. Tranzitornye ishemicheskie ataki. M.: GJeOTARMedia, 2016; 224 s. Russian.

2. Dzhejms F Tul. Sosudistye zabolevanija golovnogo mozga. M.: GJeOTAR-Media, 2007; 612 s. Russian.

3. Amarenco P. One-Year Risk of Stroke after Transient Ischemic Attack or Minor Stroke. N Engl J Med. 2016; 374 (16): 1533-42. DOI: 10/1056/NEJMoa1412981.

4. Stahovskaya LV. Tranzitornaja ishemicheskaja ataka. Farmateka. Klinicheskie rekomendacii. 2017; (2): 34-45. Russian.

5. Poltavceva OV. Kognitivnye narushenija u pacientov s arterial'noj gipertenziej i tranzitornoj ishemicheskoj atakoj. Sibirskij medicinskij zhurnal. 2014; 29 (1): 39-43. Russian.

6. Bivard A, Lillicrap T, Maréchal B. Transient Ischemic Attack Result in Delayed Brain Atrophy and Cognitive Declaine. Stroke. 2018; 49 (2): 384-90.

7. Lobzin SV, Lobzin VYu, Amurova TR, Mirzaeva LM, Nikishina OA, Nikiforova LG, i dr. Diskussionnye voprosy diagnostiki i patogeneticheskoj terapii hronicheskoj cerebral'noj ishemii $s$ kognitivnymi narushenijami. Medicinskij alfavit. Nevrologija i psihiatrija. 2018; 1 (1): 5-14. Russian.

8. Folstein MF, Folstein SE, McHugh PR. «Mini-mental state»: a practical method for grading the cognitive state of patients for the clinician. Journal of Psychiatric Research. 1975; 12 (3): 189-98.

9. Zigmond AS, Snaith RP. The Hospital Anxiety and Depression scale. Acta Psychiatr Scand. 1983; (67): 361-70.

10. Zaxarov VV, Vaxnina NV. Insul't i kognitivnye narushenija. Zhurnal nevrologii i psihiatrii im. N. N. Korsakova (pril. Insul't). 2008; (22): 6-21. Russian.

11. Damulin IV. Sosudistaja demencija: patogenez, diagnostika lechenie. Farmateka. 2010; (7): 13-8. Russian.

12. Hachinski V. World Stroke Day 2008: «Little strokes, Big Trouble». Stroke. 2008; 39 (9): 2407-8.

\section{Литература}

1. Учиям Ш. Транзиторные ишемические атаки. М.: ГЭОТАРМедиа, 2016; 224 с.

2. Джеймс Ф. Тул. Сосудистые заболевания головного мозга. М.: ГЭОТАР-Медиа, 2007; 612 с.

3. Amarenco P. One-Year Risk of Stroke after Transient Ischemic Attack or Minor Stroke. N Engl J Med. 2016; 374 (16): 1533-42. DOI: 10/1056/NEJMoa1412981.

4. Стаховская Л. В. Транзиторная ишемическая атака. Фарматека. Клинические рекомендации. 2017; (2): 34-45.

5. Полтавцева О. В. Когнитивные нарушения у пациентов о артериальной гипертензией и транзиторной ишемической атакой. Сибирский медицинский журнал. 2014; 29 (1): 39-43.

6. Bivard A, Lillicrap T, Maréchal B. Transient Ischemic Attack Result in Delayed Brain Atrophy and Cognitive Declaine. Stroke. 2018; 49 (2): 384-90.

7. Лобзин С. В., Лобзин В. Ю., Амурова Т. Р., Мирзаева Л. М., Никишина О. А., Никифорова Л. Г. и др. Дискуссионные вопросы диагностики и патогенетической терапии хронической церебральной ишемии с когнитивными нарушениями. Медицинский алфравит. Неврология и психиатрия. 2018; 1 (1): 5-14.

8. Folstein MF, Folstein SE, McHugh PR. «Mini-mental state:» a practical method for grading the cognitive state of patients for the clinician. Journal of Psychiatric Research. 1975; 12 (3): 189-98.

9. Zigmond AS, Snaith RP. The Hospital Anxiety and Depression scale. Acta Psychiatr Scand. 1983; (67): 361-70.

10. Захаров В. В., Вахнина Н. В. Инсульт и когнитивные нарушения. Журнал неврологии и психиатрии им. Н. Н. Корсакова (прил. Инсульт). 2008; (22): 6-21.

11. Дамулин И. В. Сосудистая деменция: патогенез, диагностика и лечение. Фарматека. 2010; (7): 13-8.

12. Hachinski V. World Stroke Day 2008: «Little strokes, Big Trouble». Stroke. 2008; 39 (9): 2407-8.
13. Maleina AYu, Kolokolov OV, Lukna EV. Rol' tranzitornoj ishemicheskoj ataki $v$ vozniknovenii kognitivnyh narushenij (obzor). Saratovskij nauchno-medicinskij zhurnal. 2016; 12 (2): 273-7. Russian.

14. Gudkova W, Shanina TV, Petrova EA, Stahovskaya LV. Tranzitornaja ishemicheskaja ataka-mul'tidisciplinarnaja problema. Nevrologija. Nejropsihiatrija. Psihosomatika. 2012; (3): 20-4. Russian.

15. Spurgeon L, James G, Sackley C. The Hospital Anxiety and Depression Scale: a pilot study to examine its latent structure and the link between psychological state and symptom severity in transient ischaemic attack patients. Psychol Health Med. 2016; 21 (5): 632-8.

16. Ihle-Hansen $\mathrm{H}$, Thommessen $\mathrm{B}$, Fagerland $\mathrm{MW}$, Oksengård $\mathrm{AR}$, Wyller TB, Engedal K, at al. Effect on anxiety and depression of a multifactorial risk factor intervention program after stroke and TIA: a randomized controlled trial. Aging Ment Health. 2014; 18 (5): 540-6.

17. Spurgeon L, James G, Sackley C. Subjective experiences of transient ischaemic attack: a repertory grid approach. Disabil Rehabil. 2013; 35 (26): 2205-12.

18. Boss HM, Van Schaik SM, Deijle IA, de Melker EC, van den Berg BT, Scherder EJ, at al. A randomised controlled trial of aerobic exercise after transient ischaemic attack or minor stroke to prevent cognitive decline: the MovelT study protocol. BMJ. Open. 2014; 4 (12): e007065.

19. Boss HM, Van Schaik SM, Deijle IA, de Melker EC, van den Berg BT, Scherder EJ, at al. Safety and feasibility of post-stroke care and exercise after minor ischemic stroke or transient ischemic attack: MotiveS \& MovelT. NeuroRehabilitation. 2014; 34 (3): 401-7.

20. Kjörk E, Blomstrand C, Carlsson G, Lundgren-Nilsson A, Gustafsson C. Daily life consequences, cognitive impairment, and fatigue after transient ischemic attack. Acta Neurologica Scandinavica. 2016; 133 (2): 103.

13. Малеина А. Ю., Колоколов О. В., Лукна Е. В. Роль транзиторной ишемической атаки в возникновении когнитивных нарушений (обзор). Саратовский научно-медицинский журнал. 2016; 12 (2): 273-7.

14. Гудкова В. В., Шанина Т. В., Петрова Е. А., Стаховская Л. В. Транзиторная ишемическая атака-мультидисциплинарная проблема. Неврология. Нейропсихиатрия. Психосоматика. 2012; (3): 20-4.

15. Spurgeon L, James G, Sackley C. The Hospital Anxiety and Depression Scale: a pilot study to examine its latent structure and the link between psychological state and symptom severity in transient ischaemic attack patients. Psychol Health Med. 2016; 21 (5): 632-8.

16. Ihle-Hansen $\mathrm{H}$, Thommessen $\mathrm{B}$, Fagerland $\mathrm{MW}$, Oksengård $\mathrm{AR}$, Wyller TB, Engedal K, at al. Effect on anxiety and depression of a multifactorial risk factor intervention program after stroke and TIA: a randomized controlled trial. Aging Ment Health. 2014; 18 (5): 540-6.

17. Spurgeon L, James G, Sackley C. Subjective experiences of transient ischaemic attack: a repertory grid approach. Disabil Rehabil. 2013; 35 (26): 2205-12.

18. Boss HM, Van Schaik SM, Deijle IA, de Melker EC, van den Berg BT, Scherder EJ, at al. A randomised controlled trial of aerobic exercise after transient ischaemic attack or minor stroke to prevent cognitive decline: the MovelT study protocol. BMJ. Open. 2014; 4 (12): e007065.

19. Boss HM, Van Schaik SM, Deijle IA, de Melker EC, van den Berg BT, Scherder EJ, at al. Safety and feasibility of post-stroke care and exercise after minor ischemic stroke or transient ischemic attack: MotiveS \& MovelT. NeuroRehabilitation. 2014; 34 (3): 401-7.

20. Kjörk E, Blomstrand C, Carlsson G, Lundgren-Nilsson A, Gustafsson C. Daily life consequences, cognitive impairment, and fatigue after transient ischemic attack. Acta Neurologica Scandinavica. 2016; 133 (2): 103. 